\title{
Analisis Teknis dan Ekonomis Pembangunan Kapal Ikan 30GT Konstruksi FRP Metode Vacuum Infusion
}

\author{
Rengga Eka Putra Atmanegara, Triwilaswandio Wuruk Pribadi, dan Mohammad Sholikhan Arif \\ Jurusan Teknik Perkapalan, Fakultas Teknologi Kelautan, Institut Teknologi Sepuluh Nopember (ITS) \\ Jl. Arief Rahman Hakim, Surabaya 60111 Indonesia \\ e-mail: triwilas.its@gmail.com
}

\begin{abstract}
Abstrak- Produksi kapal ikan 30GT konstruksi FRP di Indonesia masih menggunakan metode laminasi hand lay up. Metode hand lay up memiliki kekurangan pada kebutuhan jam orang dan kualitas produksi. Metode vacuum infusion merupakan salah satu metode laminasi fibreglass yang memiliki keunggulan. Tujuan tugas akhir ini adalah untuk menganalisis secara teknis dan ekonomis produksi kapal ikan 30GT konstruksi FRP menggunakan metode laminasi vacuum infusion. Pertama, produksi kapal ikan 30GT konstruksi FRP diobservasi. Kedua, data produksi kapal ikan 30GT konstruksi FRP dikumpulkan. Ketiga, menganalisis teknis dan ekonomis pembangunan kapal ikan 30GT konstruksi FRP metode laminasi hand lay up dan vacuum infusion yang telah dilakukan. Hasil dari penerapan metode vacuum infusion pada produksi kapal ikan 30GT konstruksi FRP mengalami pengurangan sebesar 7,26\%. Kualitas produksi vacuum infusion lebih baik $22,83 \%$ dibandingkan hand lay up. Dari hasil analisis ekonomis, biaya produksi kapal ikan 30GT konstruksi FRP metode laminasi vacuum infusion lebih mahal 12,9\% dari pada metode laminasi hand lay up. Produktivitas tenaga kerja metode laminasi vacuum infusion lebih tinggi $24,94 \%$ dari pada metode laminasi hand lay up. Pembangunan galangan kapal konstruksi FRP metode vacuum infusion membutuhkan biaya investasi sebesar Rp 14.383.141.000 dan Payback Period (PP) pada tahun ke-10.
\end{abstract}

Kata Kunci-Fibre Reinforced Plastic (FRP), Kapal Ikan 30GT, dan Vacuum Infusion

\section{PENDAHULUAN}

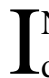
NKAMINA merupakan salah satu program kerja unggulan dari Kementerian Kelautan dan Perikanan Republik Indonesia. Dimana program kerja tersebut adalah program pembangunan $1000 \mathrm{kapal}$ ikan ukuran 30GT untuk diberikan kepada nelayan. Program tersebut bertujuan untuk meningkatkan hasil tangkapan nelayan. Program pembangunan 1000 kapal ikan 30GT dilaksanakan pada tahun 2010-2014. Namun dalam proses pembangunan 1000 kapal ikan selama tahun 2010-2014, hanya dapat diselesaikan 735 kapal ikan. Dari 735 kapal ikan 30GT, terdapat 335 kapal menggunakan konstruksi Fibre Reinforced Plastic (FRP) dan 400 kapal menggunakan konstruksi kayu. [1]

Berdasarkan info dari direktorat jenderal perikanan tangkap Kemeterian Kelautan dan Perikanan RI, akan dibuat 3.325 unit kapal dengan beragam ukuran. Kapal penangkap ukuran kurang dari 5 GT sebanyak 1.020 unit, kapal penangkap ukuran 5GT sebanyak 1.020 unit, kapal penangkap ukuran 10 GT sebanyak 1.000 unit, kapal penangkap ukuran 20 GT sebanyak 250 unit, kapal penangkap ukuran 30 GT sebanyak 30 unit dan kapal angkut ukuran 30 GT dengan pendingin sebanyak 5 unit.[2]

Material yang digunakan pada pembangunan kapal ikan 30GT di Indonesia adalah Fibre Reinforced Plastic (FRP) dan kayu. Material Fibre Reinforced Plastic (FRP) merupakan salah satu material utama pada proses produksi kapal. Material FRP pada proses produksi kapal memiliki beberapa keunggulan dibandingkan dengan material lain. Saat ini dalam pembuatan kapal konstruksi Fibre Reinforced Plastic (FRP) mengalami perkembangan dari jenis material dan metode laminasi yang digunakan pada produksi kapal konstruksi FRP. Dalam hal metode laminasi seperti metode chopper gun dan vacuum infusion. Namun karena metode chopper gun memiliki banyak kelemahan, metode tersebut sudah tidak digunakan kembali.

Saat ini perkembangan metode vacuum infusion di Indonesia sudah diterapkan oleh beberapa galangan. Hal tersebut dikarenakan metode laminasi vacuum infusion yang memiliki kelebihan dibandingkan metode laminasi hand lay-up ataupun chopper gun dalam proses produksi kapal konstruksi FRP. Kelebihan tersebut adalah memiliki lapisan kulit yang lebih tipis namun kuat, kebutuhan material resin yang lebih sedikit, jumlah jam orang yang lebih sedikit, dan hasil produksi yang lebih baik. Namun dalam penerapan metode vacuum infusion tentunya sebuah galangan harus menyediakan sarana dan prasarana yang memadai dan tentunya biaya investasi pengembangan peralatan produksi.

\section{TINJAUAN PUSTAKA}

\section{A. Kapal Inka Mina}

Program Pembangunan Kapal Penangkap Ikan berukuran diatas 30 GT atau yang dikenal dengan sebutan Inka Mina merupakan program unggulan Kementerian Kelautan dan Perikanan Republik Indonesia dalam meningkatkan pendapatan dan kesejahteraan nelayan kecil. Pembangunan 
kapal penangkap ikan berukuran diatas 30 GT pada hakekatnya ditujukan untuk meningkatkan produksi hasil tangkapan kapal nelayan, meningkatkan kesejahteraan khususnya nelayan, menjaga kelestarian sumber daya ikan dan lingkungannya serta untuk menjaga kedaulatan wilayah Negara Kesatuan Republik Indonesia.[3]

\section{B. Material Kapal Konstruksi FRP}

Dalam pembangunan kapal konstruksi Fibre Reinforced Plastic (FRP), terdapat elemen material utama atau material dasar. Material tersebut diantaranya yaitu reinforcement, resin, dan core material. Reinforcement atau penguat yang banyak digunakan pada industri galangan kapal adalah Fibre Reinforced Plastic (FRP). Hal tersebut dikarenakan biaya yang relatif murah dibandingkan penguat yang lain. Resin adalah salah satu bahan dasar yang digunakan dalam industri pembuatan kapal konstruksi Fibre Reinforced Plastic (FRP). katalis adalah material yang memiliki fungsi yang sama dengan hardener yaitu untuk mempercepat reaksi proses polimerisasi, namun digunakan sebagai pasangan polyester resin dan vynil ester resin. Gelcoat adalah material yang digunakan sebagai lapisan terluar dari lambung kapal yang akan dibangun.

\section{Metode Laminasi}

Dalam pembuatan kapal berbahan fiber terdapat 3 metode laminasi yang sering digunakan di galangan kapal konstruksi FRP. Berikut merupakan penjelasan tentang metode laminasi [4]:

\section{1) Metode Hand Lay Up}

Metode hand lay up merupakan metode dasar dalam pembangunan kapal fibre. Metode ini merupakan metode laminasi yang paling mudah dan paling sederhana. Kekurangan metode ini adalah tidak maksimalnya hasil penyatuan dari lapisan atau susunan antara fibre dan resin pada badan kapal yang terbentuk.

\section{2) Metode Chopper Gun}

Metode laminasi chooper gun dibutuhkan alat yang berbentuk seperti pistol yang akan menembakkan potongan fiber dengan resin ke seluruh lapisan cetakan (mold) yang kemudian disatukan dengan roll. Pada pelapisan menggunakan teknik chopper gun hanya dapat menggunakan fiber dalam bentuk gulungan benang (Spray Gun Roving).

\section{3) Metode Vacuum Infusion}

Metode vacuum infusion merupakan salah satu metode pencetakan tertutup atau sistem Resin Transfer Moulding (RTM). Dimana dalam sistem Resin Transfer Moulding (RTM), resin disuntikkan ke dalam suatu cetakan tertentu kemudian bagian atasnya ditutup dengan cetakan yang kaku, namun pada vacuum infusion cetakan atas diganti dengan plastik film. Keuntungan yang dimiliki oleh metode vacuum infusion diantaranya adalah hasil laminasi yang lebih tipis, merata, dan lebih kuat. Metode laminasi vacuum infusion juga memiliki kelemahan dibandingkan dengan metode lain, dimana kelemahan tersebut terletak pada investasi awal peralatan yang digunakan dan biaya produksi yang lebih mahal. Peralatan yang digunakan pada metode laminasi vacuum infusion sedikit berbeda dengan metode lainnya.

\section{Proses Pembangunan Kapal Konstruksi FRP}

Proses pembangunan kapal konstruksi FRP tentunya sangat berbeda dengan proses pembangunan kapal berbahan material lain seperti baja, aluminium, dan kayu. Proses produksi kapal FRP lebih ringan dibandingkan kapal baja. Hal tersebut dikarenakan pada pembangunan kapal konstruksi FRP harus dimulai dengan persiapan pembuatan mold. . Dimana pada proses produksi kapal baja terdapat pekerjaan seperti pengelasan, assembly, cutting, bending. Kapal FRP hanya dibuat dengan modal awal sebuah cetakan atau mold untuk membentuk kapal tersebut. Pembuatan mold biasanya menggunakan material FRP yang memiliki ketebalan dan kuat tarik tertentu, seperti menggunakan CSM 600 atau juga dapat dibuat dengan kayu dan triplek. Berikut adalah alur pembuatan kapal berbahan FRP. [5]

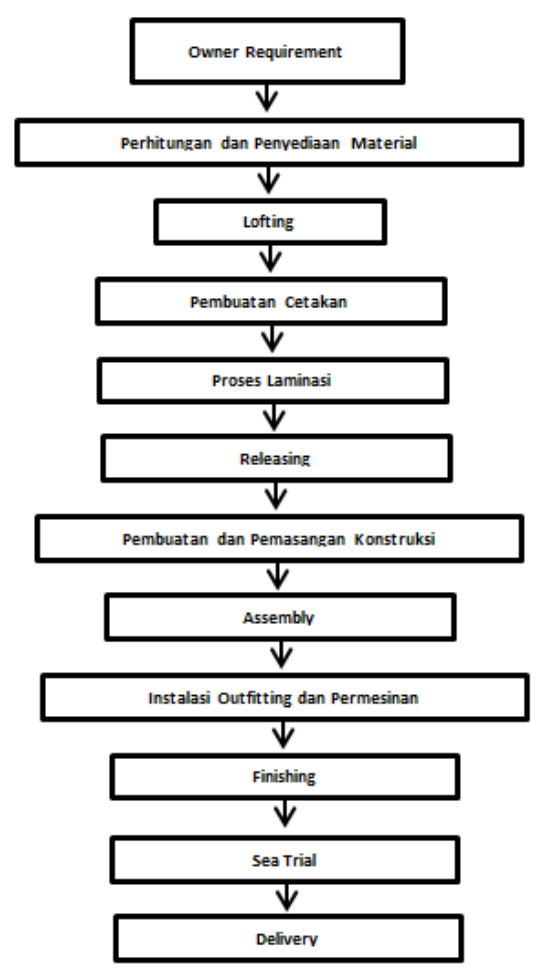

Gambar. 1. Diagram alur pembangunan kapal konstruksi FRP.

\section{E. Kuat Tarik dan Kuat Lentur Material}

Sifat kuat tarik adalah kemampuan material dalam menerima gaya tarik pada suatu pengujian (tensile test). Untuk mendapatkan nilai kuat lentur maka perlu dilakukan pengujian lentur (bending test) ini berguna untuk mengetahui efek dari permukaan terhadap kekuatan material.[6]

Berdasarkan data yang diambil dari referensi penelitihan sebelumnya yang dilakukan pengujian material, menunjukkan bahwa. Hasil pengujian tarik dan bending dari metode laminasi hand lay up dan vacuum Infusion pada pembangunan kapal patroli bea cukai 10meter tersebut menunjukkan bahwa 
Tabel 1.

Pengujian Tarik Material

\begin{tabular}{|c|c|c|c|c|}
\multicolumn{5}{c}{ Pengujian Tarik Material } \\
\hline \multicolumn{4}{c|}{ Kuat Tarik $\left(\mathrm{Kg} / \mathrm{cm}^{2}\right)$} \\
\hline Keterangan & \multicolumn{1}{c|}{ Hand Lay $\boldsymbol{U p}$} & \multicolumn{2}{c|}{ Vacuum Infusion } \\
\hline Stadar BKI & 1000 & $\mathrm{Kg} / \mathrm{cm}^{2}$ & 1000 & $\mathrm{Kg} / \mathrm{cm}^{2}$ \\
\hline $\begin{array}{c}\text { Hasil } \\
\text { Pengujian }\end{array}$ & 2463,28 & $\mathrm{Kg} / \mathrm{cm}^{2}$ & 1644,47 & $\mathrm{Kg} / \mathrm{cm}^{2}$ \\
\hline
\end{tabular}

Tabel 2.

Pengujian Lentur Material

\begin{tabular}{|c|c|c|c|c|}
\hline \multicolumn{4}{|c|}{ Kuat Lentur $\left(\mathrm{Kg} / \mathrm{cm}^{2}\right)$} \\
\hline Keterangan & Hand Lay Up & \multicolumn{2}{|c|}{ Vacuum Infusion } \\
\hline Stadar BKI & 1500 & $\mathrm{Kg} / \mathrm{cm}^{2}$ & 1500 & $\mathrm{Kg} / \mathrm{cm}^{2}$ \\
\hline $\begin{array}{c}\text { Hasil } \\
\text { Pengujian }\end{array}$ & 3007,58 & $\mathrm{Kg} / \mathrm{cm}^{2}$ & 2583 & $\mathrm{Kg} / \mathrm{cm}^{2}$ \\
\hline
\end{tabular}

metode vacuum infusion memiliki hasil kuat tarik dan bending yang lebih baik dibandingkan dengan metode hand lay up.

\section{HASIL DAN PEMBAHASAN}

\section{A. Data Kapal Ikan 30GT Konstruksi FRP}

Jenis kapal ikan 30GT konstruksi FRP yang digunakan adalah pole and line. Berikut merupakan spesifikasi kapal ikan 30GT konstruksi FRP [7] :

$\begin{array}{ll}\text { LOA (Length Over All) } & =18,0 \mathrm{~m} \\ \text { LPP (Length PerPendicular) } & =15,3 \mathrm{~m} \\ \text { Lwl (Length Water Line) } & =16,5 \mathrm{~m} \\ \mathrm{~B} \text { moulded (Breadth) } & =4,2 \mathrm{~m} \\ \mathrm{H} \text { midship (Height) } & =1,9 \mathrm{~m} \\ \text { Draft } & =1,2 \mathrm{~m} \\ \mathrm{Cb} & =0,6 \\ \mathrm{~V}(\text { Kecepatan Dinas) } & =9 \mathrm{knot}\end{array}$

Perlu dilakukan perhitungan luas dan ukuran konstruksi kapal yang didasarkan oleh rules BKI tentang "Fibre Reinforced Ships 1996”. [8]

Tabel 3.

Luas Konstruksi

\begin{tabular}{|c|l|r|l|}
\hline No & \multicolumn{1}{|c|}{ Jenis Material } & \multicolumn{2}{|c|}{ Luas ${\left(\mathbf{m}^{2}\right)}^{\mathbf{2}}$} \\
\hline $\mathbf{1}$ & Lunas & 4.81 & $\mathrm{~m} 2$ \\
\hline $\mathbf{2}$ & Kuliat Alas & 118.47 & $\mathrm{~m} 2$ \\
\hline $\mathbf{3}$ & Kulit Sisi & 31,84 & $\mathrm{~m} 2$ \\
\hline $\mathbf{4}$ & Pembujur Sisi & 6,13 & $\mathrm{~m} 2$ \\
\hline $\mathbf{5}$ & Centre Girder & 16,60 & $\mathrm{~m} 2$ \\
\hline $\mathbf{6}$ & Side Girder & 42,82 & $\mathrm{~m} 2$ \\
\hline $\mathbf{7}$ & Gading & 4,63 & $\mathrm{~m} 2$ \\
\hline $\mathbf{8}$ & Floor/Wrang & 30.67 & $\mathrm{~m} 2$ \\
\hline $\mathbf{9}$ & Dinding Sekat & 36,20 & $\mathrm{~m} 2$ \\
\hline $\mathbf{1 0}$ & Penegar Sekat & 55.50 & $\mathrm{~m} 2$ \\
\hline $\mathbf{1 1}$ & Geladak & 58.94 & $\mathrm{~m} 2$ \\
\hline $\mathbf{1 2}$ & Dinding Bangunan Atas & 40,68 & $\mathrm{~m} 2$ \\
\hline $\mathbf{1 3}$ & Balok Geladak & & \\
\hline
\end{tabular}

\begin{tabular}{|c|l|r|l|}
\hline $\mathbf{1 4}$ & Pembujur Geladak & 40,03 & $\mathrm{~m} 2$ \\
\hline $\mathbf{1 5}$ & Penegar Bangunan Atas & 46.49 & $\mathrm{~m} 2$ \\
\hline
\end{tabular}

\section{B. Analisis Teknis}

Selanjutnya akan dilakukan analisis secara teknis dari penerapan metode vacuum infusion pada pembangunan kapal ikan 30GT konstruksi FRP. Dimana nantinya dibandingkan dengan metode hand lay up. Aspek teknis yang termasuk didalamnya adalah :

\section{1) Jumlah Laminasi}

Dalam penentuan jumlah laminasi yang digunakan pada pembangunan kapal ikan 30GT konstruksi FRP menggunakan metode hand lay up dan metode vacuum infusion yang didasarkan oleh rules BKI tentang "Fibre Reinforced Ships 1996”. Berikut merupakan perbandingan jumlah laminasi :

Tabel 4.

Jumlah Lapisan Laminasi

\begin{tabular}{|l|r|l|r|l|}
\hline \multicolumn{1}{|c|}{ Item } & \multicolumn{2}{c|}{ Hand Lay Up } & \multicolumn{2}{c|}{$\begin{array}{c}\text { Vacuum } \\
\text { Infusion }\end{array}$} \\
\hline Lunas & 14 & Lapisan & 13 & Lapisan \\
\hline Alas & 11 & Lapisan & 11 & Lapisan \\
\hline Sisi samping & 10 & Lapisan & 9 & Lapisan \\
\hline Geladak & 7 & Lapisan & 7 & Lapisan \\
\hline Gading & 6 & Lapisan & 5 & Lapisan \\
\hline Balok Geladak & 6 & Lapisan & 5 & Lapisan \\
\hline Pembujur Sisi & 6 & Lapisan & 5 & Lapisan \\
\hline Pembujur Geladak & 6 & Lapisan & 5 & Lapisan \\
\hline Penegar Sekat dan Tangki & 4 & Lapisan & 4 & Lapisan \\
\hline Centre Girder & 13 & Lapisan & 12 & Lapisan \\
\hline Side Girder & 13 & Lapisan & 12 & Lapisan \\
\hline Side Girder Kamar Mesin & 13 & Lapisan & 12 & Lapisan \\
\hline Floor/Wrang & 6 & Lapisan & 5 & Lapisan \\
\hline Dinding Sekat & 6 & Lapisan & 5 & Lapisan \\
\hline Bangunan Atas dan Kabin & 7 & Lapisan & 7 & Lapisan \\
\hline Penegar Bangunan Atas & 5 & Lapisan & 4 & Lapisan \\
\hline
\end{tabular}

Dari tabel diatas diketahui bahwa pada metode hand lay up memiliki jumlah laminasi lebih banyak dibandingkan dengan metode vacuum infusion.

\section{2) Kebutuhan Material}

Setelah didapatkan jumlah laminasi dari setiap konstruksi, maka dapat dilakukan perhitungan kebutuhan material. Kebutuhan material pada proses pembangunan kapal ikan 30GT konstruksi FRP menggunakan metode hand lay up dan vacuum infusion memiliki perbedaan pada jumlah jenis material. Kebutuhan material pada pembangunan kapal ikan 30GT konstruksi FRP dikelompokkan pada 3 kelompok material, yaitu : material utama, material penunjang, dan 
material tambahan Berikut merupakan analisis teknis kebutuhan material :

Tabel 6.

Kebutuhan Material Utama

\begin{tabular}{|l|r|r|r|l|}
\hline \multicolumn{1}{|c|}{ Item } & \multicolumn{2}{c|}{$\begin{array}{r}\text { Vacuum } \\
\text { Infusion }\end{array}$} \\
\hline Mirror Glaze Meguain & 114,00 & $\mathrm{Klg}$ & 114,00 & $\mathrm{Klg}$ \\
\hline PVA & 5,00 & $\mathrm{Kg}$ & 5,00 & $\mathrm{Kg}$ \\
\hline Gelcoat & 158,06 & $\mathrm{Kg}$ & 158,06 & $\mathrm{Kg}$ \\
\hline Catalyst Mepoxe & 46,29 & $\mathrm{Kg}$ & & \\
\hline Catalyst Percumyl H & & & 30,17 & $\mathrm{Kg}$ \\
\hline Cobalt N8\% & 23,15 & $\mathrm{Kg}$ & 15,09 & $\mathrm{Kg}$ \\
\hline Resin Yukalac 157 & 4608,35 & $\mathrm{Kg}$ & & \\
\hline Resin Ripoxy R800-EX(VI) & & & 3017,30 & $\mathrm{Kg}$ \\
\hline Chopped Strand Mat 300 & 1,90 & $\mathrm{roll}$ & 1,90 & $\mathrm{roll}$ \\
\hline Chopped Strand Mat & 38,72 & $\mathrm{roll}$ & & \\
\hline Woven Roving 800 & 33,81 & $\mathrm{roll}$ & 82,04 & $\mathrm{roll}$ \\
\hline $\begin{array}{l}\text { Multipurpose Adhesive } \\
\text { Aerosol }\end{array}$ & & & 157,80 & $\mathrm{Bot}$ \\
\hline Aerosil & & & $\mathrm{ol}$ \\
\hline Talc Lioning & 3,95 & $\mathrm{Kg}$ & 3,95 & $\mathrm{Kg}$ \\
\hline Honey Comb 20mm & 1,58 & $\mathrm{Kg}$ & 1,58 & $\mathrm{Kg}$ \\
\hline Pigment Blue & 4,00 & $\mathrm{Lbr}$ & 17,00 & $\mathrm{Lbr}$ \\
\hline Pigment Super White & 1,85 & $\mathrm{Kg}$ & 4,76 & $\mathrm{Kg}$ \\
\hline Dempul & 42,00 & $\mathrm{Kg}$ & 42,00 & $\mathrm{Kg}$ \\
\hline Kayu Meranti (uk.12x8) & 165 & $\mathrm{Btg}$ & 165 & $\mathrm{Btg}$ \\
\hline Kayu Meranti (uk.7x5) & 27 & $\mathrm{Btg}$ & 27 & $\mathrm{Btg}$ \\
\hline Kayu Meranti (uk.6x4) & 32 & $\mathrm{Btg}$ & 32 & $\mathrm{Btg}$ \\
\hline
\end{tabular}

Tabel 7.

Kebutuhan Material Penunjang

\begin{tabular}{|l|r|r|r|l|}
\hline \multicolumn{1}{|c|}{ Item } & \multicolumn{2}{c|}{ Hand Lay Up } & \multicolumn{2}{c|}{$\begin{array}{c}\text { Vacuum } \\
\text { Infusion }\end{array}$} \\
\hline Majun & 10 & $\mathrm{Kg}$ & 10 & $\mathrm{Kg}$ \\
\hline Selotip & 8 & Roll & 8 & Roll \\
\hline Amplas Gerinda panjang & 50 & $\mathrm{M}$ & 50 & $\mathrm{M}$ \\
\hline Amplas Gerinda Bulat & 20 & $\mathrm{Bh}$ & 20 & $\mathrm{bh}$ \\
\hline Kawat Las & 3 & Dus & 3 & Dus \\
\hline Masker & 8 & Bks & 8 & Bks \\
\hline Green HDPE Flow Media & & & 4 & Roll \\
\hline Red HDPE Flow Media & & & 1 & Roll \\
\hline Wrapping Spiral Bands K- & & & 44 & Bks \\
\hline Nylon Peel Ply & & & 9 & Roll \\
\hline Benang & & & 1 & Roll \\
\hline Bagging film BF150A-6000 & & & 1 & Roll \\
\hline
\end{tabular}

Tabel 8.

Kebutuhan Material Alat

\begin{tabular}{|l|c|c|c|c|}
\hline \multicolumn{1}{|c|}{ Item } & \multicolumn{2}{|c|}{ Hand Lay Up } & \multicolumn{2}{c|}{$\begin{array}{c}\text { Vacuum } \\
\text { Infusion }\end{array}$} \\
\hline Kuas 2" & 48 & $\mathrm{Bh}$ & 12 & $\mathrm{Bh}$ \\
\hline Kuas 3" & 60 & $\mathrm{Bh}$ & 15 & $\mathrm{Bh}$ \\
\hline Kuas Roll & 96 & $\mathrm{Bh}$ & 24 & $\mathrm{Bh}$ \\
\hline Kuas Roll Aluminium & 24 & $\mathrm{Bh}$ & 6 & $\mathrm{Bh}$ \\
\hline Gunting & 18 & $\mathrm{Bh}$ & 18 & $\mathrm{Bh}$ \\
\hline Ember & 18 & $\mathrm{Bh}$ & 18 & $\mathrm{Bh}$ \\
\hline Cutter & 18 & $\mathrm{Bh}$ & 18 & $\mathrm{Bh}$ \\
\hline
\end{tabular}

Dari data tersebutdiketahui bahwa pada penggunaan metode vacuum infusion kebutuhan material mengalami peningkatan dibandingkan dengan metode hand lay up.

\section{3) Kebutuhan Peralatan Peralatan}

Pada galangan kapal fiberglass terdapat beberapa fasilitas produksi pada galangan. Fasilitas pada galangan yang menerapkan metode hand lay up dan metode laminasi lain tidak terdapat perbedaan.Fasilitas yang tersedia di galangan memiliki standar yang sama. Sehingga pada bab ini hanya akan membahas tentang peralatan produksi. Peralatan produksi merupakan alat yang digunakan pada proses produksi dan dapat digunakan kembali pada produksi berikutnya. Peralatan produksi yang digunakan pada proses pembangunan kapal ikan 30GT konstruksi FRP menggunakan metode laminasi hand lay up lebih sederhana dibandingkan dengan metode yang lain. Berikut merupakan perbandingan kebutuhan peralatan produksi pada proses pembangunan kapal ikan 30GT konstruksi FRP :

Tabel 9.

Kebutuhan Peralatan

\begin{tabular}{|l|c|c|c|l|}
\multicolumn{1}{|c|}{ Item } & \multicolumn{2}{c|}{ Hand Lay Up } & \multicolumn{2}{|c|}{$\begin{array}{l}\text { Vacuum } \\
\text { Infusion }\end{array}$} \\
\hline $\begin{array}{l}\text { Resin Infusion Pump } \\
25 \mathrm{~m}^{3} \text { /hour }\end{array}$ & - & - & 6 & Set \\
\hline Flow Tube E10 merk justus & - & - & 12 & Bungkus \\
\hline T-Fitting & - & - & 36 & Buah \\
\hline Vacuum Gauge & - & - & 1 & Set \\
\hline Resin Trap & - & - & 12 & Buah \\
\hline Spring Clamp & - & - & 36 & Buah \\
\hline Gayung & 24 & buah & 24 & buah \\
\hline $\begin{array}{l}\text { Mesin Bor Listrik dan } \\
\text { Manual }\end{array}$ & 2 & set & 2 & set \\
\hline Gergaji Ukir & 6 & buah & 6 & buah \\
\hline Mesin Gerinda & 4 & buah & 4 & buah \\
\hline Gergaji Besi & 2 & buah & 2 & buah \\
\hline Gergaji Kayu & 1 & buah & 1 & buah \\
\hline Pita Pengukur & 2 & buah & 2 & buah \\
\hline Palu Karet & 2 & buah & 2 & buah \\
\hline Sikat dan Sapu logam & 4 & buah & 4 & buah \\
\hline Palu Baja & 2 & buah & 2 & buah \\
\hline
\end{tabular}

Dari Tabel 9 diatas diketahui bahwa dengan penggunaan metode laminasi vacuum infusion dibutuhkan penambahan beberapa kebutuhan peralatan produksi.

\section{4) Kebutuhan Jam Orang}

Perhitungan kebutuhan jam orang didasarkan pada hasil observasi lapangan yang dilakukan di galangan kapal fibreglass yang menerapkan metode laminasi hand lay up dan vacuum infusion. Berikut merupakan perbandingan kebutuhan jam orang pada proses produksi kapal ikan 30GT konstruksi FRP :

Tabel 10.

Kebutuhan Material Alat

\begin{tabular}{|l|c|c|c|c|}
\hline \multicolumn{1}{|c|}{ Jenis Pekerjaan } & \multicolumn{2}{c|}{ Hand Lay Up } & \multicolumn{2}{c|}{$\begin{array}{c}\text { Vacuum } \\
\text { Infusion }\end{array}$} \\
\hline Laminasi Kapal & 762 & JO & 391 & JO \\
\hline Total Jam Orang & 5110 & JO & 4739 & JO \\
\hline
\end{tabular}

Dari Tabel 10 diketahui bahwa penggunaan metode vacuum infusion memiliki 371 jam orang lebih sedikit dibandingkan 
dengan penggunaan metode hand lay up pada pembangunan kapal ikan 30GT konstruksi FRP.

\section{Analisis Ekonomis}

Dalam pembangunan kapal ikan 30GT konstruksi FRP tentunya tidak terlepas faktor ekonomis. Selanjutnya akan dibahas tentang analisis ekonomis pada pembangunan kapal ikan 30GT konstruksi FRP metode vacuum infusion yang akan dibandingkan dengan metode hand lay up.

\section{1) Biaya Tenaga Kerja Langsung}

Biaya tenaga kerja langsung adalah biaya yang dikeluarkan untuk kebutuhan tenaga langsung selama proses produksi. Dalam perhitungan biaya kebutuhan tenaga kerja ini akan dibagi menurut tugas masing-masing. Perhitungan biaya tenaga kerja didasarkan pada perhitungan kebutuhan jam orang pada proses pembangunan kapal ikan 30GT konstruksi FRP metode hand lay up ataupun metode vacuum infusion.

Dengan asumsi kebutuhan orang sebagai berikut :
a. Mandor (M)
$=1$ Orang
b. Tukang Fiber/Kayu (Tk)
$=3$ Orang
c. Pembantu (P)
$=4$ Orang
d. Mekanik Mesin \& Listrik $(\mathrm{MM})=1$ Orang
e. Tukang Cat (Tc)
$=3$ Orang

Dengan asumsi biaya/JO dari tiap pekerja pada metode hand lay up, sebagai berikut :
a. Mandor (M)
$=\operatorname{Rp} 20.000$
b. Tukang Fiber/Kayu (Tk)
$=\operatorname{Rp} 15.000$
c. Pembantu (P)
$=\operatorname{Rp} 10.000$
d. Mekanik Mesin \& Listrik (MM) $=$ Rp 20.000
e. Tukang Cat (Tc)
$=\operatorname{Rp} 15.000$

Sedangkan asumsi biaya/JO dari tiap pekerja pada metode vacuum infusion, sebagai berikut :
a. Mandor (M)
$=\operatorname{Rp} 35.000$
b. Tukang Fiber/Kayu (Tk)
$=\operatorname{Rp} 30.000$
c. Pembantu (P)
$=\operatorname{Rp} 20.000$
d. Mekanik Mesin \& Listrik (MM) $=$ Rp 30.000
e. Tukang Cat $(\mathrm{Tc})=\mathrm{Rp} 25.000$

Sehingga didapatkan perhitungan berikut :

Tabel 12.

Biaya Tenaga Kerja Langsung

\begin{tabular}{|c|c|c|c|c|}
\hline \multirow{2}{*}{ Tugas } & \multicolumn{2}{|c|}{ Hand Lay Up } & \multicolumn{2}{|c|}{ Vacuum Infusion } \\
\hline & JO & Total & JO & Total \\
\hline $\mathbf{M}$ & 961 & Rp 19.220.000 & 887 & Rp 31.045.000 \\
\hline $\mathbf{T k}$ & 2883 & $\operatorname{Rp} 43.245 .000$ & 2661 & $\operatorname{Rp~} 79.830 .000$ \\
\hline $\mathbf{P}$ & 1922 & Rp 19.220 .000 & 1774 & $\operatorname{Rp} 35.480 .000$ \\
\hline MM & 1922 & Rp 38.440 .000 & 1774 & Rp 53.220.000 \\
\hline Tc & 2883 & Rp 43.245.000 & 2661 & Rp 66.525 .000 \\
\hline Total & & Rp163.370.000 & & Rp 266.100.000 \\
\hline
\end{tabular}

Dari Tabel 12. diatas, diketahui bahwa biaya tenaga kerja langsung pada proses pembangunan 1 kapal ikan 30GT konstruksi FRP menggunakan metode vacuum infusion lebih murah dibandingkan dengan metode hand lay up.

\section{2) Biaya Pembangunan Kapal Ikan 30GT Konstruksi FRP}

Selanjutnya dapat diketahui besarnya biaya pembangunan kapal ikan 30GT konstruksi FRP dari penerapan metode hand lay up dan vacuum infusion. Dimana data biaya pembangunan kapal ikan 30GT didasarkan pada perhitungan dan data RAB pembangunan kapal ikan 30GT konstruksi FRP di galangan.Berikut merupakan perhitungan biaya pembangunan kapal ikan 30GT konstruksi FRP :

Tabel 13.

Biaya Material Kasko Kapal

\begin{tabular}{|c|c|c|c|c|}
\hline Item & \multicolumn{2}{|c|}{ Hand Lay Up } & \multicolumn{2}{|c|}{ Vacuum Infusion } \\
\hline $\begin{array}{l}\text { PEKERJAAN KONSTRUKSI } \\
\text { (KASKO KAPAL) }\end{array}$ & $\mathrm{Rp}$ & 539.092 .000 & $\mathrm{Rp}$ & 768.079 .650 \\
\hline INSTALASI-INSTALASI & $\mathrm{Rp}$ & 42.150 .000 & $\mathrm{Rp}$ & 42.150 .000 \\
\hline AKOMODASI & $\mathrm{Rp}$ & 10.265 .000 & $\mathrm{Rp}$ & 10.265 .000 \\
\hline SISTEM KEMUDI & $\mathrm{Rp}$ & 20.500 .000 & $\mathrm{Rp}$ & 20.500 .000 \\
\hline $\begin{array}{l}\text { PERALATAN LISTRIK DAN } \\
\text { PENERANGAN }\end{array}$ & $\mathrm{Rp}$ & 11.565 .000 & $\mathrm{Rp}$ & 11.565 .000 \\
\hline $\begin{array}{l}\text { PERALATAN } \\
\text { KESELAMATAN } \\
\end{array}$ & $\mathrm{Rp}$ & 15.887 .000 & $\mathrm{Rp}$ & 15.887 .000 \\
\hline $\begin{array}{l}\text { PERALATAN NAVIGASI } \\
\text { DAN KESELAMATAN } \\
\end{array}$ & $\mathrm{Rp}$ & 46.700 .000 & $\mathrm{Rp}$ & 46.700 .000 \\
\hline $\begin{array}{l}\text { PERALATAN LABUH DAN } \\
\text { TAMBAT }\end{array}$ & $\mathrm{Rp}$ & 8.235 .000 & $\mathrm{Rp}$ & 8.235 .000 \\
\hline $\begin{array}{l}\text { PERALATAN } \\
\text { DAPUR/MASAK }\end{array}$ & $\mathrm{Rp}$ & 2.970 .000 & $\mathrm{Rp}$ & 2.970 .000 \\
\hline $\begin{array}{l}\text { PEKERJAAN MESIN DAN } \\
\text { POMPA }\end{array}$ & $\mathrm{Rp}$ & 308.600 .000 & $\mathrm{Rp}$ & 308.600 .000 \\
\hline ALAT PENANGKAPAN & $\mathrm{Rp}$ & 228.500 .000 & $\mathrm{Rp}$ & 28.500 .000 \\
\hline SISTEM PENDINGIN & $\mathrm{Rp}$ & 225.000 .000 & $\mathrm{Rp}$ & 225.000 .000 \\
\hline BIAYA UMUM & $\mathrm{Rp}$ & 86.500 .000 & $\mathrm{Rp}$ & 86.500 .000 \\
\hline Total & $\mathbf{R p}$ & 1.545.964.000 & $\mathbf{R p}$ & 1.774.951.650 \\
\hline
\end{tabular}

3) Evaluasi Kelayakan Investasi

Pada perhitungan biaya investasi difokuskan pada biaya investasi pembangunan galangan kapal FRP metode vacuum infusion. Dimana galangan diasumsikan galangan khusus pembangunan kapal ikan 30GT konstruksi FRP metode vacuum infusion. Sehingga dibutuhkan perhitungan pada biaya investasi tanah, bangunan, peralatan, dan perijinan. Dimana besarnya investasi galangan adalah Rp 14.383.141.000. Sedangkan keuntungan galangan pada tiap kapal adalah 25\% dari harga produksi kapal. Seingga besarya harga jual untuk 1(satu) kapal adalah Rp 2.218.689.563. Dan biaya operasional galangan selama 1(satu) tahun adalah Rp 862.800.000. Discounted factor dari tingkat inflasi sebesar $8 \%$.

Maka dari itu dapat di evaluasi bahwa dengan nilai investasi tersebut yang ditanamkan pada modal usaha, diperkirakan dapat mencapai Break Even Point pada tahun ke-10 dengan nilai Rp 3.910.360.348.

\section{Produktivitas}

Dari semua perhitungan secara teknis maka bisa didapatkan besarnya produktivitas yang terjadi antara pada saat masih menggunakan metode laminasi hand lay up dan setelah menggunakan metode vacuum infusion. Pada tugas akhir ini digunakan perbandingan yang sama antara penggunaan metode laminasi hand lay up dan metode vacuum infusion yaitu dalam satu tahun ada 1(satu) produksi kapal ikan 
30GT konstruksi FRP. Dan produktivitas ini hanya digunakan pada produksi kapal ikan 30GT konstruksi FRP. Adapun perbedaan produktivitas dari kedua fasilitas ini adalah sebagai berikut :

Tabel 14.

Perbandingan Produktivitas

\begin{tabular}{|l|c|c|}
\cline { 2 - 3 } \multicolumn{1}{c|}{} & Hand Lay Up & Vacuum Infusion \\
\hline Jumlah Kapal yang dibangun & $\mathbf{1}$ & $\mathbf{1}$ \\
\hline Berat (Ton) & 7767,57 & 9590,72 \\
\hline JO & 5110 & 4739 \\
\hline Produktivitas (Ton/JO) & $\mathbf{1 , 4 7 0}$ & $\mathbf{1 , 9 5 9}$ \\
\hline
\end{tabular}

\section{KESIMPULAN/RINGKASAN}

1) Pembangunan kapal ikan 30GT konstruksi FRP menggunakan metode hand lay up memiliki kelemahan pada hasil produksi dan kebutuhan jam orang.

2) Pembangunan kapal ikan 30GT konstruksi FRP menggunakan metode vacuum infusion dapat diterapkan. Metode vacuum infusion memiliki beberapa keuntungan pada hasil produksi dan kebutuhan jam orang yang lebih sedikit.

3) Dari hasil perhitungan aspek teknis dan ekonomis, pembangunan kapal ikan 30GT menggunakan metode vacuum infusion memiliki beberapa kelebihan pada kebutuhan jam orang, waktu produksi, kebutuhan resin, cobalt, dan, katalis serta kekuatan dari hasil produksi dibandingkan dengan metode hand lay up. Namun pada biaya kebutuhan material, biaya kebutuhan tenaga kerja langsung, dan biaya produksi pada penerapan metode vacuum infusion memiliki biaya lebih tinggi dibandingkan dengan metode hand lay up. Sehingga nilai jual kapal ikan 30GT konstruksi FRP metode vacuum infusion lebih mahal 12,9\% dibandingkan dengan metode hand lay up. Investasi galangan difokuskan pada penerapan metode vacuum infusion. Dimana dilakukan perhitungan investasi pada pembangunan galangan kapal FRP. Sehingga didapatkan pay back period pada tahun ke-14.

\section{UCAPAN TERIMA KASIH}

Penulis ingin mengucapkan terima kasih kepada pihak-pihak yang membantu penyelesaian Tugas Akhir ini, yaitu:

1. Bapak Ir. Triwilaswandio Wuruk Pribadi, M.Sc. selaku Dosen Pembimbing dan Dosen Wali atas bimbingan dan motivasinya selama pengerjaan dan penyusunan Tugas Akhir ini.

2. Bapak Mohammad Sholikhan Arif, S.T.,M.T. selaku Dosen Pembimbing atas bimbingan dan motivasinya selama pengerjaan dan penyusunan Tugas Akhir ini.

3. Bapak Ir. Wasis Dwi Aryawan, M.Sc., Ph.D. selaku Ketua Jurusan Teknik Perkapalan yang banyak memberikan inspirasi kepada penulis.

4. Bapak Ir. Soejitno, Ir. Heri Supomo, M,Sc., Imam Baihaqi, ST.,M.T., Hasanudi, ST.,MT., dan Ibu Sri Rejeki Wahyu Pribadi, ST.,MT. selaku dosen penguji dan penelaah.
5. Kementerian Kelautan dan Perikanan Republik Indonesia atas bantuan dalam pengerjaan dan penyusunan Tugas Akhir ini.

6. PT. Biro Klasifikasi Indonesia atas bantuan dalam pengerjaan dan penyusunan Tugas Akhir ini.

7. PT. Mina Anugrah Sukses, PT. Marathon Pasific Marine, CV. Bajo Boat, CV. Javanese Boat atas bantuan dalam pengerjaan dan penyusunan Tugas Akhir ini.

8. Hafez Haris Ariya Suyadi, S.ST. yang telah membantu dalam memperoleh data dan memberikan saran dalam penyelesaian tugas akhir ini.

\section{DAFTAR PUSTAKA}

[1] KKP. (2013). Daftar Rincian Alokasi Kapal Ikan Inka Mina Berdasarkan Provinsi/Kabupaten/Kota. Jakarta: Kementerian Kelautan dan Perikanan.

[2] Direktorat Jenderal Perikanan Tangkap. (2015, 12 11). KKP Prioritaskan Pembangunan Kapal di Tahun 2016. Dipetik 12 23, 2015, dari Direktorat Jenderal Perikanan Tangkap Kementerian Kelautan dan Perikanan Republik Indonesia: http://www.djpt.kkp.go.id/index.php/arsip/c/1836/KKPPrioritaskan-Pembangunan-Kapal-di-Tahun2016/?category_id=14

[3] Kementerian Kelautan dan Perikanan Republik Indonesia. (2013). Inka Mina. Dipetik Maret 27, 2015, dari http://simantap.djpt.kkp.go.id/inka-mina

[4] Putra, Gerry Liston. (2012). Perancangan Galangan Boat Sistem Vacuum Infusion. Depok: Universitas Indonesia.

[5] Coackley, Ned,et. al. (1991). Fishing Boat Construction: 2 Building a Fiberglass Fishing Boat. Roma: Food and Agriculture Organization of the United Nations.

[6] Suyadi, Hafez Haris Ariya (2015). Pengaruh Metode Hand Lay Up dan Vacuum Infusion Terhadap Sifat Mekanik Material Fiberglass Rainforced Plastic (FRP) Pada Pembuatan Kapal Patroli Bea Cukai. Surabaya: Politeknik Perkapalan Negeri Surabaya.

[7] DKP. (2013). Pengadaan Kapal Ikan 30GT. Kupang: Dinas Kelautan dan Perikanan NTT.

[8] BKI. (1996). Rules and Regulation for the Classification and Construction of Ships (Volume V Fibreglass Reinforced Plastic Ships). Jakarta: Biro Klasifikasi Indonesia. 